\title{
Formation and stability of magmatic segments in the Main Ethiopian and Afar rifts
}

\author{
Erin Beutel ${ }^{\mathrm{a}, *}$, Jolante van Wijk ${ }^{\mathrm{b}}$, Cindy Ebinger ${ }^{\mathrm{c}}$, Derek Keir ${ }^{\mathrm{d}}$, Andrea Agostini ${ }^{\mathrm{e}}$ \\ a Department of Geology and Environmental Geosciences, College of Charleston, 66 George Street, Charleston, SC 29424-0001, United States \\ b University of Houston, Houston, TX, United States \\ c University of Rochester, Rochester, NY, United States \\ d University of Leeds, Leeds, UK \\ e Dipartimento di Scienze della Terra, University of Florence, Florence, Italy
}

\section{A R T I C L E I N F O}

\section{Article history:}

Received 15 September 2009

Received in revised form 3 February 2010

Accepted 4 February 2010

Available online 24 March 2010

Editor: R.D. van der Hilst

\section{Keywords:}

East African Rift

continental rifting

magmatic intrusion

stress

lithospheric extension

rupturing continental lithosphere

\begin{abstract}
A B S T R A C T
As rifting progresses to seafloor spreading, extension within the continental crust commonly is accommodated by a combination of fault slip and dike intrusion. Consistent patterns in the spatial arrangement of long-lived magma intrusion zones in the Ethiopian and Afar rift sectors, East Africa, suggest that the magma intrusions help to localize strain during repeated rifting episodes. Within the broad Main Ethiopian Rift, extensional deformation has localized since $\sim 3 \mathrm{~m}$.y. in narrow magmatic segments, that are oriented oblique to the orientation of the Miocene border faults, but (sub-) orthogonal to the extension direction. Numerical models combined with geophysical and geological observations from East Africa are used to examine the viability of self-sustaining magmatic segmentation. Initiation of the magmatic segments is shown to result from magma injections, which focus strain in narrow elongated zones. During magmatic phases of segment evolution the segments are weak, and extensional stresses localize at the rift tips, promoting along-axis lengthening. During amagmatic phases of extension, the numerical models predict strain localization within the magmatic segments and, to a lesser extent, broadly distributed extension within the rift zone. This promotes segment stability; the segments remain the preferred location for magma intrusion during new magmatic phases. These results are applied to the formation and maintenance of MER segmentation. The Fentale-Dofen segment is currently in a non-magmatic phase of extension; the Dabbahu segment in the Red Sea Rift is currently experiencing a rifting episode and therefore is in a transient magmatic cycle. The observed patterns of instantaneous localized deformation, seismicity, and dike intrusions sometimes propagating beyond the tip of the magmatic segments occur as predicted by the models.
\end{abstract}

(c) 2010 Elsevier B.V. All rights reserved.

\section{Introduction}

Continental rift zones have a segmented character, whereby the rift is divided along-axis into basins that are typically $40-100 \mathrm{~km}$ long. The large offset fault systems bounding the basins are linked by transfer faults and/or relay ramps in accommodation zones (Ebinger, 1989; Morley et al., 1990). The individual segments may have an alternating asymmetry, with border faults on opposite sides of the rift in adjacent segments (Bosworth, 1987; Ebinger et al., 1987; Chapin and Cather, 1994). These patterns develop in rifts with extension directions both orthogonal and highly oblique to pre-rift structures (e.g., Ebinger et al., 1987). During the early stages of rifting most of the strain across the basin is accommodated by slip along the border fault systems, with basin breadth determined by the flexural rigidity of the extending plate, crustal thickness, and rift obliquity (e.g., Hayward and Ebinger,

\footnotetext{
* Corresponding author.

E-mail addresses: beutele@cofc.edu (E. Beutel), jwvanwijk@uh.edu (J.van Wijk), ebinger@earth.rochester.edu (C. Ebinger), D.Keir@leeds.ac.uk (D. Keir), andrea.agostini@unifi.it (A. Agostini).
}

1996; Jackson and Blenkinsop, 1997; Ebinger et al., 1999; van Wijk, 2005; Corti et al., 2007). Examples include the East African Rift system and the Rio Grande Rift in the southwestern US (e.g., Chapin and Cather, 1994; Hayward and Ebinger, 1996; Upcott et al., 1996).

As rifting progresses to continental rupture, the basin architecture and distribution of strain across the basins evolves with the changing plate rheology. Few rifts worldwide are in this stage of development, and the late rift stage is obscured by post-rift sediments on most rifted margins. The seismically and volcanically active northern Main Ethiopian Rift (MER) and southern Red Sea Rift in the Afar depression are two such regions, affording the opportunity to trace the evolution of along-axis segmentation during progressive rifting stages (Fig. 1). In the MER, strain jumped about 3 m.y. ago from the border faults to $\sim 15 \mathrm{~km}$-wide, $60 \mathrm{~km}$-long zones of localized strain and magma intrusions in the mid- to shallow crust, as imaged with seismic, gravity, and MT data (e.g., Wolfenden et al., 2004; Keir et al., 2009). These new magmatic segments are oblique to the original border faults, and are arranged en echelon along the length of the rift. Segments in the southern Red Sea Rift show similar dimensions, but their spatial arrangement is more complex owing to proximity to the Afar triple junction (Fig. 1). 


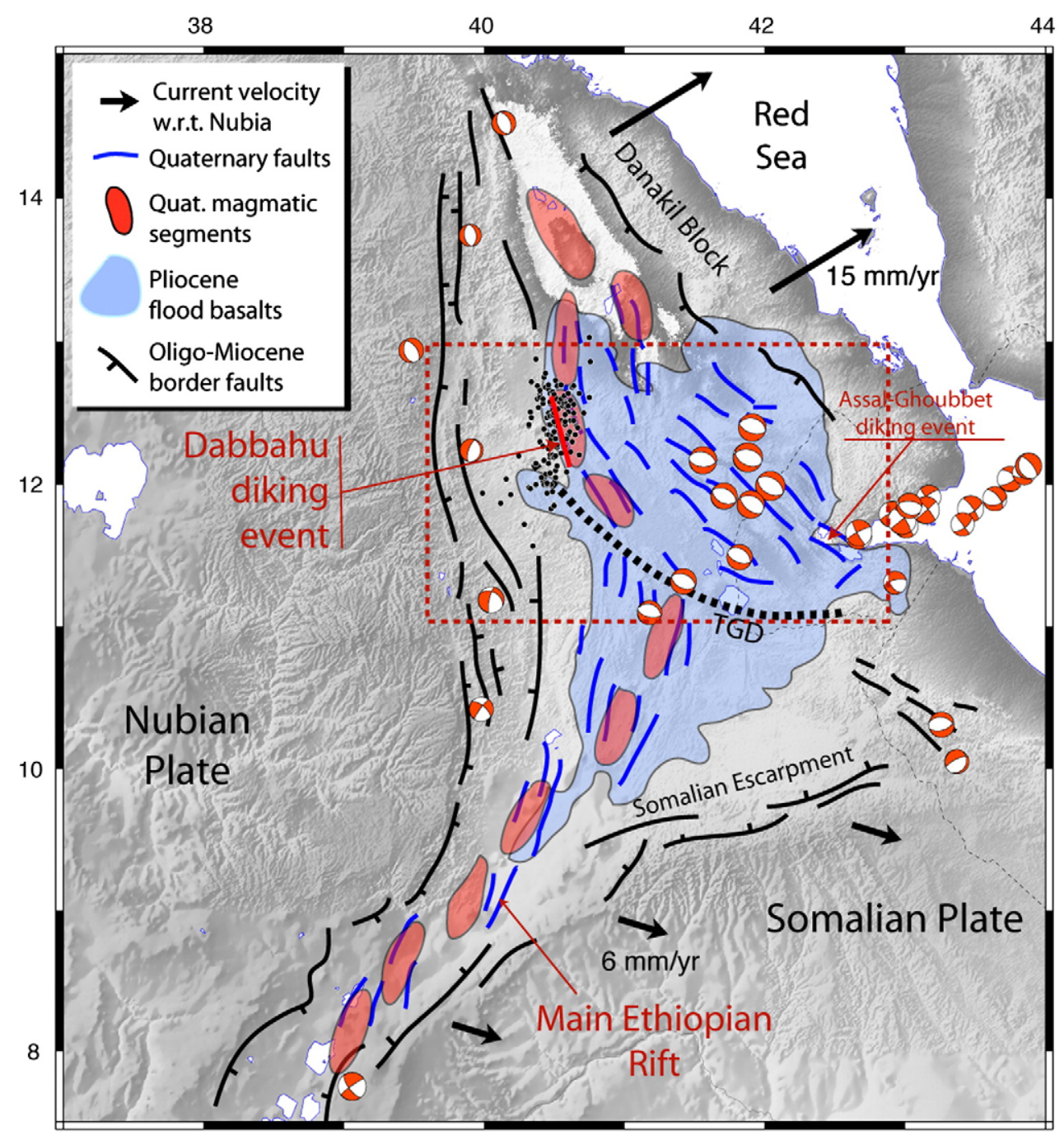

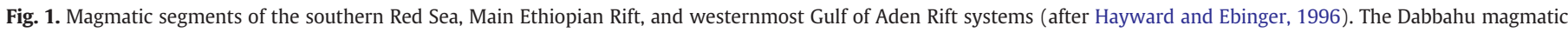

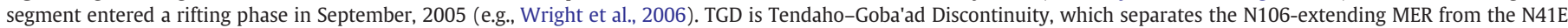
extending southern Red Sea Rift zone.

This late-stage along-axis segmentation structure has a strong resemblance with oblique, slow-spreading mid-ocean ridges such as the Mohns Ridge in the Norwegian-Greenland Sea and the Reykjanes Ridge south of Iceland. In these spreading ridges, an en echelon pattern of magmatic segments is located within the spreading system, whereby the magmatic segments are oriented sub-orthogonal to the spreading direction (Géli et al., 1994; Dauteuil and Brun, 1996). These magmatic segments are the loci of magma injections and extensional deformation (Géli et al., 1994). Magmatic injections appear to play an important role in maintaining the stable segmented structure of the oblique spreading ridges (van Wijk and Blackman, 2007).

Here we focus on the initiation and maintenance of magmatic segments within the northern Main Ethiopian Rift and Afar depression, where an ongoing rifting episode provides additional insights. Numerical models are used to study the effects of magma emplacement on the lithospheric stress field, and are compared with geophysical and geological observations. The stress field in the northern Main Ethiopian Rift zone is calculated during the various stages of magma emplacement and cooling. We find that magma intrusions are able to control segment formation. Once formed, stress localizes at the ends of the segments during magmatic phases when magma injections accommodate stretching within the magmatic segment. During amagmatic phases of extension, stresses are broadly distributed across the fault-bounded rift basin, and concentrated within the magmatic segments, in agreement with observations. Renewed magma injections will then preferentially occur in the magmatic segments, promoting the stability of the segmented structure. The patterns predicted by our models are observed in the Ethiopian and Afar rifts, suggesting strong similarities between continental and oceanic rifting processes during the late stages of continental rupture. Thus, the along-axis segmentation of mid-ocean ridges may initiate with the development of magmatic segmentation, prior to continental break-up.

\section{Tectonic setting}

The Main Ethiopian and Afar rift systems developed within the Afar flood basalt province above a broad region of anomalously low velocity mantle (e.g. Montelli et al., 2004; Benoit et al., 2006; Bastow et al., 2008), (Figs. 1, 2, and 3). A synthesis of ${ }^{40} \mathrm{Ar} /{ }^{39} \mathrm{Ar}$ data shows that up to $2 \mathrm{~km}$ of flood basalts and rhyolites were erupted throughout the southernmost Red Sea region at around 31 Ma (e.g. Hofmann et al., 1997; Pik, 2003), roughly coeval with the onset of rifting between Arabia and Africa (Wolfenden et al., 2005). Less widespread and probably related volcanism affected SW Ethiopia 45-39 Ma (e.g., Ebinger et al., 2000), and volcanism continued outside the 
developing rifts until around $11 \mathrm{Ma}$ (Kieffer et al., 2004). The volcanic units overlying uplifted Mesozoic marine sequences now form a $\sim 2500$ m-high plateau on both sides of the southern Red Sea and western Gulf of Aden (Fig. 1). The long-lived volcanism and high relief indicates that the upper mantle thermal anomaly is also long-lived.

The southern Red Sea Rift was initiated by $\sim 29 \mathrm{Ma}$, and progressed to seafloor spreading by $4 \mathrm{Ma}$ north of $14^{\circ} \mathrm{N}$ (Fig. 1). WNW-directed extension within the Main Ethiopian Rift, the third arm of the Afar triple junction, commenced at around $18 \mathrm{Ma}$ in southwestern Ethiopia, and propagated northward into the Afar depression after $11 \mathrm{Ma}$ (Wolfenden et al., 2004; WoldeGabriel et al., 1990). Alternatively, Rooney et al. (2007) propose that the northern MER formed from southward propagation of the Red Sea Rift. However such a model is inconsistent with the current kinematic disconnect between the Red Sea Rift and MER axes evidenced at the surface by the abrupt termination of the MER at the Tendaho Goba'ad discontinuity in central Afar (Fig. 1). Irrespective of propagation direction, the MER is a much younger, and less evolved, rift than the Red Sea and Gulf of Aden rifts, rather than a failed rift arm (Wolfenden et al., 2004).

Seismic and geochemical data provide constraints on melting and melt emplacement beneath the MER. P- and S-wave tomography models indicate that the lithosphere-asthenosphere boundary lies at $\sim 70 \mathrm{~km}$ below the surface with anomalous low velocity zones in the upper asthenosphere (Bastow et al., 2005; 2008). Major element compositions of Quaternary mafic lavas from the MER are derived from parental melts generated at depths of $60-75 \mathrm{~km}$ (Rooney et al., 2005; Furman et al., 2006), consistent with the tomographic estimates of the lithosphere-asthenosphere boundary. Analyses of SKS and crustal splitting observations indicate that partial melt accumulates in vertically oriented dykes that cross-cut the lithosphere (Kendall et al., 2005; 2006; Keir et al., 2005).

Geophysical and geochemical data show magmatic modification to the crust throughout the plateau region, and its relation to faultcontrolled extension (Figs. 1 and 2). Crustal thickness is greatest (40$50 \mathrm{~km}$ ) beneath the uplifted plateau flanking the rift valley, with evidence for around $10 \mathrm{~km}$ of magmatic underplating beneath the uplifted plateau where volcanism spans $>40$ m.y. (Mackenzie et al., 2005; Dugda et al., 2005; Keranen and Klemperer, 2008) (Fig. 2). Beneath the MER, crustal thickness decreases from $\sim 38 \mathrm{~km}$ in the south to $24 \mathrm{~km}$ beneath Fentale volcano in the southern Afar depression, with a significant decrease north of Gedemsa volcano (Dugda et al., 2005; Maguire et al., 2006) (Fig. 3). Up to 25\% of the crust beneath the northern MER and Afar depression is new igneous material, but with minor amounts of crustal stretching south of Fentale volcano $\left(9^{\circ} \mathrm{N}\right.$; Figs. 2 and 3) (Mackenzie et al., 2005; Tiberi et al., 2005; Dugda et al., 2005; Cornwell et al., 2006). Ayalew et al. (2006) interpreted systematic changes in the chemistry of felsic lavas as increasing amounts of crustal melting over the period 31 Ma to present, consistent with the spatial localization of strain.

The northernmost Main Ethiopian Rift is bounded by Mid-Miocene border faults that bound half-grabens (e.g., WoldeGabriel et al., 1990; Wolfenden et al., 2004). Within the rift lies a right-stepping, en echelon system of aligned Quaternary eruptive centers (Ebinger and Casey, 2001; Wolfenden et al., 2004). Limited GPS data suggest deformation is now concentrated in magmatic segments. An across-rift profile shows the majority of strain is accommodated in a $30 \mathrm{~km}$-wide zone of the rift axis (Bilham et al., 1999; Bendick et al., 2006). The pattern of strain shown by geodesy is supported by historic and local seismicity patterns that indicate that N45-trending border faults are relatively inactive and that earthquakes are predominantly within the less than $30 \mathrm{~km}$-wide magmatic segments (Ayele and Kulhánek, 2000; Keir et al., 2006). In addition, seismic moment release during 1960-2000 accounts for less than 50\% strain predicted from timeaveraged rates of plate separation, indicating that a significant component of strain is accommodated by magma injection (Hofstetter and Beyth, 2003).
Geodetic, fault slip, and seismicity data place strong observational constraints on the current opening direction along the MER, and seafloor spreading patterns constrain motions back to about 3.2 Ma. Fernandes et al. (2004) predict $6-7 \mathrm{~mm} / \mathrm{yr}$ opening in a direction $\mathrm{N} 95 \pm 5$, compared to $\sim 20 \mathrm{~mm} / \mathrm{yr}$ at N50 in the southernmost Red Sea (Vigny et al., 2006). Pizzi et al. (2006) found an extension direction of N95. Keir et al. (2006) estimated an extension direction of $\mathrm{N} 103 \pm 12$ from an inversion of focal mechanism solutions for tectonic earthquakes, which is similar to the N109 opening direction from a single geodetic profile across the rift (Bilham et al., 1999). Chu and Gordon (1999) find an opening direction of N105 with an opening velocity of $6 \mathrm{~mm} / \mathrm{yr}$ using marine anomalies averaged over the past 3.2 m.y. The similarity of these independent estimates suggests that opening directions of $\mathrm{N} 135$ based on fault kinematic indicators alone (e.g., Acocella and Korme, 2002) may be averaging pre-3.2 Ma and present day opening directions.

\subsection{Magmatic segments in the northern MER and southern Red Sea regions}

Right-stepping, en echelon faults, fissures and chains of Quaternary eruptive centers are the locus of Quaternary strain in the northern MER (Keir et al., 2006; Bendick et al., 2006) (Figs. 1 and 2). This narrow, heavily faulted zone fades out south of $7^{\circ} \mathrm{N}$ where collapse calderas and faults occur across a much broader zone within the rift, and border faults are seismically active (Asfaw, 1992; Keir et al., 2006; Corti, 2008) (Figs. 1 and 2). The N10-striking faults and aligned volcanic chains within the Quaternary magmatic segments are oblique to the N45 strike of the large offset, Miocene border faults bounding the MER, which themselves are oblique to the N20 trend of the southern MER (e.g. Meyer et al., 1975; Pizzi et al., 2006) (Figs. 1 and 2). Silicic volcanic complexes are located at the tips of the en echelon magmatic segments in the Main Ethiopian Rift (Wolfenden et al., 2005; Casey et al., 2006) (Fig. 2). North of $10^{\circ} \mathrm{N}$ strain has migrated from large offset border faults to increasingly narrowing magmatic segments (Wolfenden et al., 2005) which are oriented oblique to sub-parallel to the border faults (Fig. 1).

The magmatic segmentation observed at the surface is mirrored in subsurface data. Tomographic images reveal an along-axis segmentation in crustal seismic velocity patterns beneath the magmatic segments. The magmatic segments are characterised by positive Bouguer anomalies (Tessema and Antoine, 2004; Tiberi et al., 2005; Cornwell et al., 2006) and underlain by anomalously high velocity material interpreted as cooled mafic intrusions (Keranen et al., 2004; Daly et al., 2008). Keranen et al. (2004) and Daly et al. (2008) tomographically imaged a right-stepping pattern of high velocities between $20 \mathrm{~km}$ and $7 \mathrm{~km}$ depth in the crust beneath magmatic segments. Bastow et al. (2005; 2008) image a NE-trending low velocity zone in the upper mantle (75-100 km depth) beneath the Ethiopian Rift. Zones of lowest seismic velocities do not directly underlie magmatic segments, but are instead offset towards the nearest rift flank, mimicking the initial fault-controlled segmentation.

Several models have been proposed for the origin of along-axis segmentation. The obliquity of Miocene border faults and Quaternary faults in the Wonji belt led Bonini et al. (1997) to propose a model of oblique extension along the border faults after a change in extension direction, which probably occurred at around 3.5 Ma to accommodate along-axis propagation in the western Gulf of Aden (Wolfenden et al., 2004; Audin et al., 2004). The magmatic segments of the northern Main Ethiopian Rift have been attributed to oblique extension, with a left-lateral component of motion along the rift floor (e.g., Mohr, 1968; Boccaletti et al., 1998). Corti (2008) replicated an along-axis magmatic segmentation with analogue models of oblique rifting, but the role of basement fabric and changes in stress field remain poorly constrained, as pre-rift basement is masked by volcanic sequences and there are no seismic reflections or well data. 

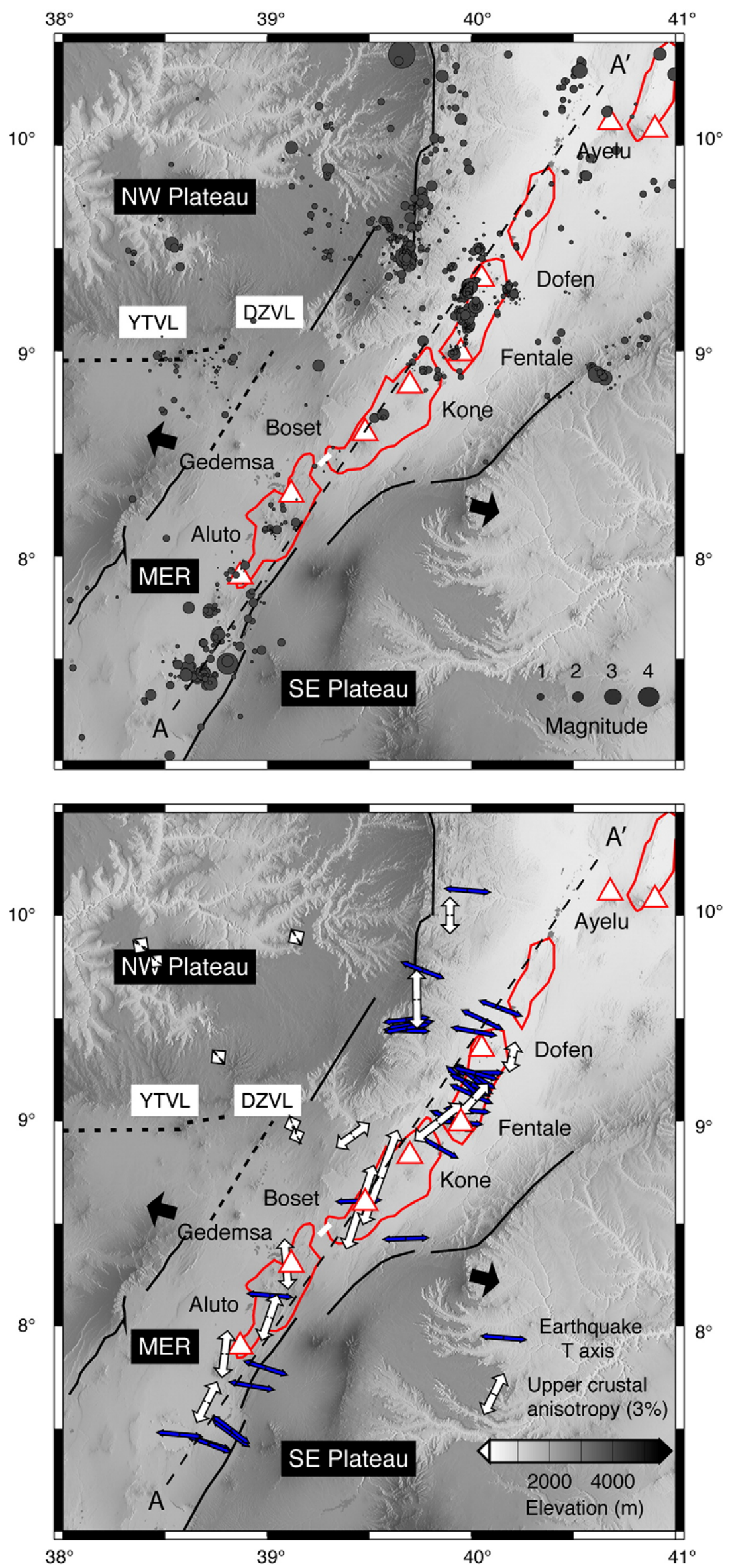


\section{Possible causes of magmatic segmentation}

While observations of the Main Ethiopian Rift (MER) discussed above suggest that internal processes may be the main controlling factor for current deformation and magmatic activity in the MER as opposed to pre-existing or outside conditions, the regional stresses and resultant thinning continue to play a major role. Two basic stresses are recognized in the MER; extensional regional stresses and loading stresses from the magmatic bodies themselves. Regionally, the MER is currently undergoing $\mathrm{N} 105^{\circ} \mathrm{E}$ trending regional extensional stress, and has been doing so for 11-18 m.y. (Wolfenden et al., 2004; WoldeGabriel et al., 1990). This long period of extension has resulted in a relatively thin elastic plate thickness; Ebinger et al. (1999) estimated an effective elastic thickness of less than $15 \mathrm{~km}$, and Keir et al. (2006) determined seismogenic thickness $<15 \mathrm{~km}$ in the northern MER and Afar regions. The thickness of the elastic plate influences the flexural behavior of the plate and the lithospheric stress field. Below we examine the role of magma intrusions on segment initiation, and stresses within the rift zone. First, magma intrusions are shown to control the location of normal faults and en echelon segment patterns. After the magmatic segments have been formed, we study the influence of their load on the stress field within the northern MER and Afar rifts.

\subsection{Magmatic segments and normal faulting}

The young magmatic segments of the MER that formed when strain on its border faults transitioned to narrow segments, are suborthogonal to the extension direction, arranged en echelon along the length of the rift. Formation of the magmatic segments could have evolved according to two end-member scenarios; 1 ) tectonic deformation (faults) developed either in en echelon segments or oblique to the extension direction, followed by magmatic intrusions; or 2) magmatic intrusions acted as the principal control on the spatial distribution of faults and segmentation. We test below the second end-member, which suggests that magmatic intrusions may have controlled segment formation and strain focus.

We use the software package Gale (Moresi et al., 2003) to study the initiation of segmentation by magma intrusions. Gale uses the finite element method to solve the equations for conservation of mass, momentum and thermal energy. The model domain consists of a three dimensional block of upper crustal material (20 km thick) with viscoplastic rheology. Thermal and rheological parameters that were used (Ranalli, 1995; Moresi et al., 2007) are temperature dependent viscosity $\eta$, according to $\eta=\eta_{0} \exp (-b T)$, with $b=0.0115$ and $\eta_{0}=1$. $10^{25}$ Pas (a viscosity of $1 \cdot 10^{25}$ Pas at shallow upper crustal depths decreases to $\sim 1.6 \cdot 10^{22}$ Pas at Moho depth); a Drucker-Prager yielding criterion with friction angle of $30^{\circ}$ and cohesion of $4.4 \cdot 10^{7} \mathrm{~Pa}$; crustal density of $2800 \mathrm{~kg} \mathrm{~m}^{-3}$; thermal expansion of $3 \cdot 10^{-5}{ }^{\circ} \mathrm{C}^{-1}$; thermal diffusivity of $1 \cdot 10^{-6} \mathrm{~m}^{2} / \mathrm{s}$; and constant crustal heat production of $1 \cdot 10^{-6} \mathrm{Wm}^{-3}$. Temperature boundary conditions were $0{ }^{\circ} \mathrm{C}$ at surface and $560{ }^{\circ} \mathrm{C}$ at the Moho. The model domain was extended in the $x$-direction. We tested a range of velocities; shown here are results with a total extension velocity of $20 \mathrm{~mm} / \mathrm{yr}$. Other parameters that were varied are the crustal temperature structure (with a Moho temperature of $\left.700{ }^{\circ} \mathrm{C}\right)$ and the background viscosity $\left(\eta_{0}\right.$,
$1 \cdot 10^{26}$ Pas). The varied parameters did not influence where shear bands (corresponding to normal faults in the lithosphere) were formed, and are not further discussed here. The magmatic intrusions were chosen to have a higher density than the crust $\left(3000 \mathrm{~kg} \mathrm{~m}^{-3}\right)$. The lateral size of the crustal domain varied between different tests, but in all tests the element size was between 0.5 and $1.5 \mathrm{~km}$ in the $x, y$ and $z$-directions.

In the first experiments, one cylindrical-shaped or box-shaped magmatic intrusion was emplaced within the brittle crust. Cylinders (indicated with ellipses in Fig. 4) were tested with radii varying from $1 \mathrm{~km}$ to $3 \mathrm{~km}$, extending from the base of the upper crust to either the surface or to $5 \mathrm{~km}$ or $10 \mathrm{~km}$ below the surface, or extending from 5 to $15 \mathrm{~km}$ depth. The box-shaped magmatic intrusion (Fig. 4A) extended from the base of the crust to $10 \mathrm{~km}$ below the surface, and was 4 or $8 \mathrm{~km}$ wide in the $x$-direction and $20 \mathrm{~km}$ long in the $y$-direction. In all cases, the location of the magmatic intrusion controlled the location where the normal fault formed (Fig. 4). The normal fault formed above the intrusion, and intersected the surface above the intrusion (Fig. 4A), so that the intrusion became part of the footwall of the structure. This was found in all models that we tested. The strike of the fault was perpendicular to the extension direction. A conjugate shear bend formed later (normal fault with opposite dip direction).

In the second set of experiments, two cylindrical intrusions were emplaced within the crust (Fig. 4B), with a lateral offset. Again, the locations of the intrusions determined where a normal fault was formed, and the strike of the faults was perpendicular to the extension direction. In the case of two intrusions, two shear bends were formed. Dependent on the spacing of the intrusions, and their lateral offset, the dip direction of the faults was either the same (shown in Fig. 4C) or different such that they formed an alternating pattern (not shown). In the latter case the faults did not extend over the entire model domain; instead the tips of the faults were in the spacing between the intrusions. Later during the modeled evolution a weaker conjugate zone of shear developed in all models.

These simple models of melt intrusion demonstrate the intimate relation between crustal intrusions and faults. Hence, as rifting progresses and magma intrudes and is stored within the crust, faults will preferentially form above the magma intrusions. Although our models explore too limited a range of parameters to determine the relationship between border fault initiation and onset of magmatic segmentation, they demonstrate the role of magma intrusion in strain localisation within the continental crust.

\subsection{Evolution of magmatic segments}

We first examine the flexure of the lithosphere alone as a result of the emplacement of en echelon magma bodies. The flexural deformation is calculated using the method described in Li et al. (2004) for 3D modeling of flexural deformation. Parameters that were used in the calculations are the plate thickness (varying between 4 and $14 \mathrm{~km}$, shown in Fig. 4 are results with plate thickness $6 \mathrm{~km}$ ), flexural rigidity (1.38 $10^{21} \mathrm{~N} / \mathrm{m}$ ), Young's modulus (70 GPa), Poisson's ratio $(0.30)$, a sedimentary fill $\left(2300 \mathrm{~kg} / \mathrm{m}^{3}\right)$, the difference between the plate density and the loading density of the magma bodies $(210 \mathrm{~kg} /$ $\mathrm{m}^{3}$ ), and dimensions of the magma body (see Fig. 4). In some calculations (e.g., Fig. 4), volcanoes were also added as loads to the top of the

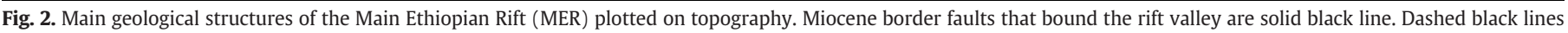

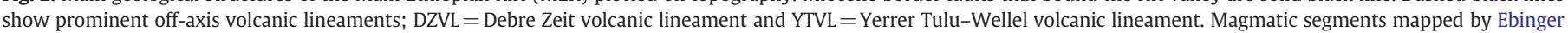

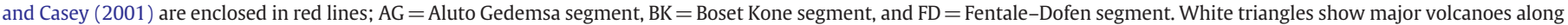

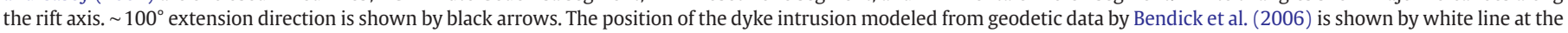

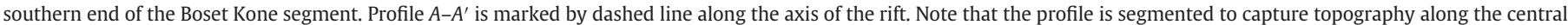

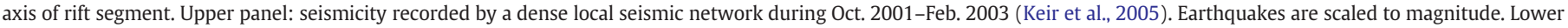

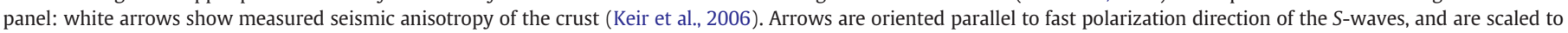
percent $S$-wave anisotropy. Blue arrows show orientation of focal mechanism T axes (Keir et al., 2006). 
A
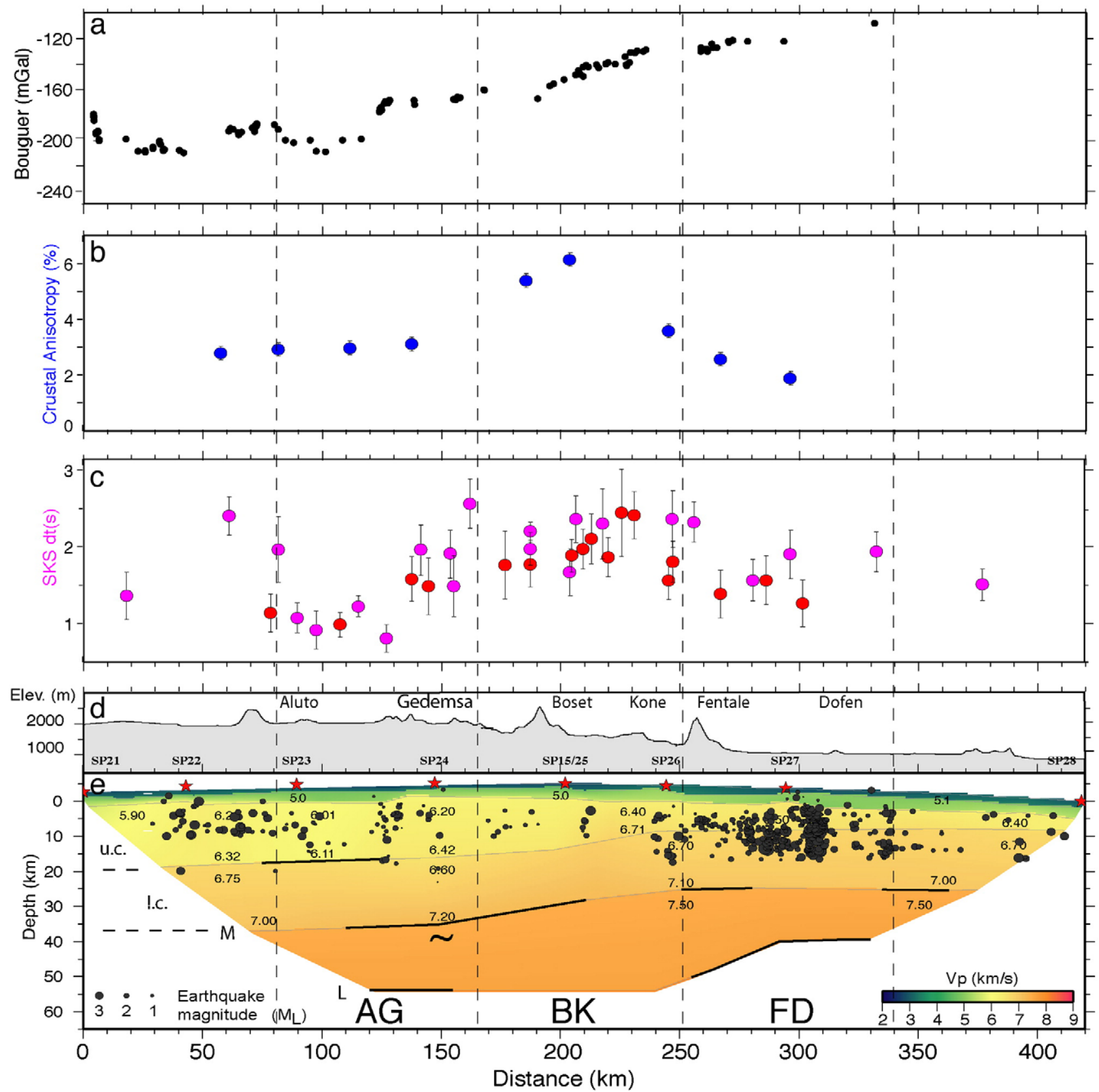

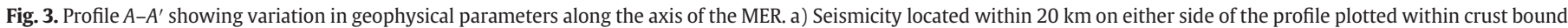

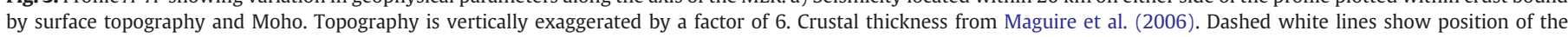

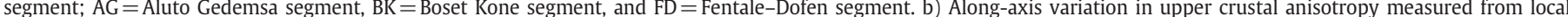

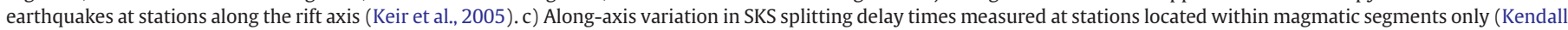
et al., 2005). d) Along-axis variation in Bouguer gravity (Tiberi et al., 2005).

plate. The size and distribution of the magmatic bodies and volcanoes were taken from Cornwell et al. (2006) and Casey et al. (2006).

The setup shown in Fig. 4 represents a single en echelon pattern. The calculations show that the elastic plate bends around the igneous bodies in a $\sim 100 \mathrm{~km}$-wide region, and in between the en echelon segments. Amplitudes of plate bending are up to $\sim 800 \mathrm{~m}$ at the location of the magmatic bodies, and up to $\sim 550 \mathrm{~m}$ in between the segments in the transfer zones. In the along-axis topography profile (Fig. 3) this deflection is not detectable, because the basin depressions are filled with sediments and flows. The magma body emplacement causes stresses in the lithosphere (see below), but the resulting deflection is too small to be detected in the Moho topography profile and is unlikely to be the main cause of the ongoing magmatic segmentation (Fig. 3). The flexure of the crust tilts the basalt flows toward the magmatic intrusions (Fig. 4E). With ongoing rifting, progressive magma intrusions toward the future break-up axis would result in a dominantly seaward dipping sequence of reflectors. Patterns in the Afar rift indicate that the magmatic segments may jump laterally, presumably in relation to linkage with adjoining segments (Wolfenden et al., 2005).

Ongoing seismic and geodetic monitoring indicates that most magmatic phases in the Main Ethiopian Rift are relatively small, resulting in diking episodes within the existing magmatic segments. To determine if and how the state (cooled and strong or hot and weak) of mafic 
A
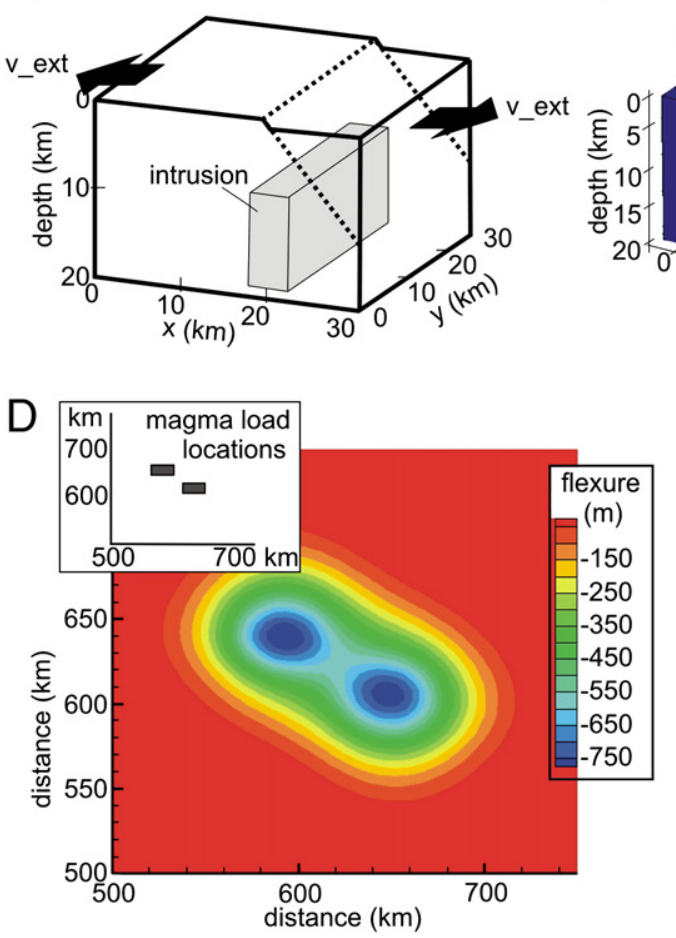

B

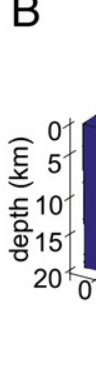

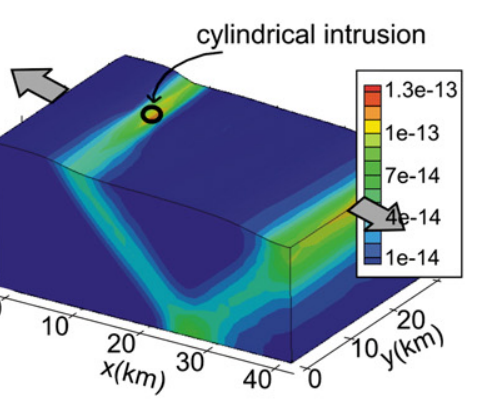

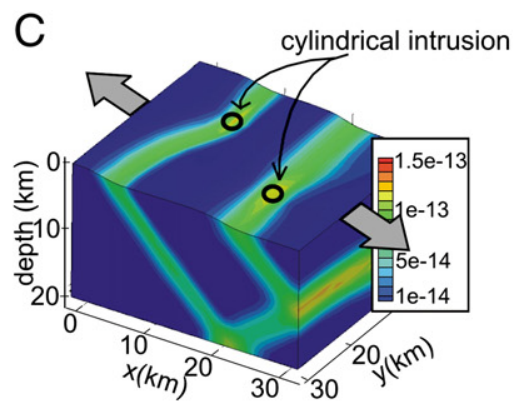

$E$

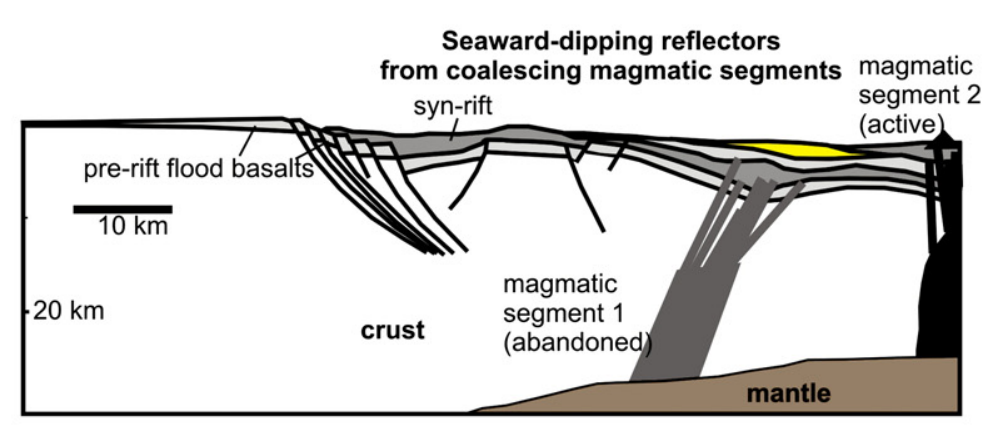

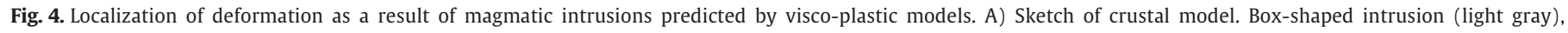

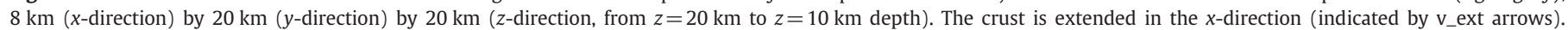

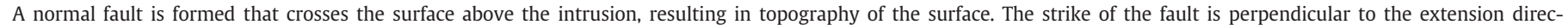

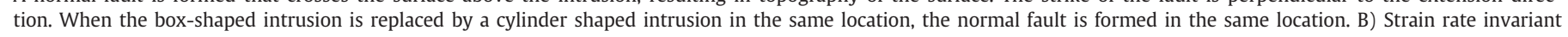

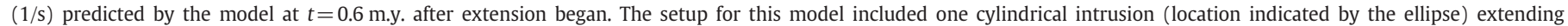

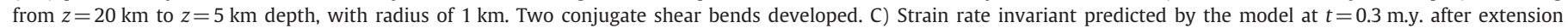

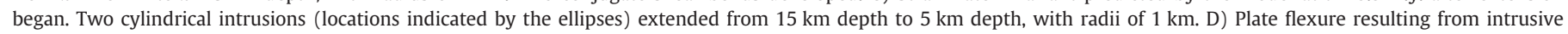

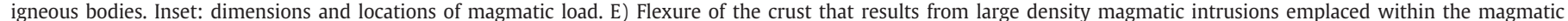

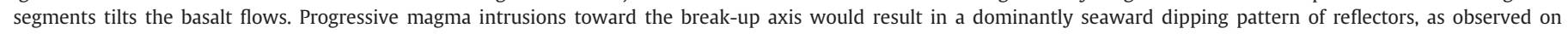
magma-dominated rifted margins. Gray tones: volcanic and volcaniclastic rocks of different age; yellow: sediments.

magmatic bodies in the MER would affect the stress field and ongoing magmatic injection a series of elastic finite element models were constructed. These models show end-member large-scale results of the effect of cooled strong mafic bodies versus hot weak mafic bodies in the lithosphere on the stress field within the MER.

\subsubsection{Methods}

We use the along-axis segmentation interpretations of Casey et al. (2006) to construct 2-D mapview and cross-sectional finite element models of the MER with varying strength magmatic intrusive bodies. The stress field generated under the various modeled conditions is calculated with the elastic finite element code of Gobat and Atkinson (1999). Each large-scale model is constructed with one element equal to $2 \mathrm{~km}$, with a maximum of 50,000 elements in the mapview model. Model inputs include the density, Young's modulus, crust and lithospheric plate thicknesses, and Poisson's ratio of the elements, which are equivalent to the rock units (Table 1 ). On the boundaries we applied forces in the $\mathrm{N} 105^{\circ} \mathrm{E}$ direction that were based on the far-field motion of the East African Rift and present day stress calculations (Fernandes et al., 2004; Bilham et al., 1999). Physical properties of the elements in the rift that we used are from Cornwell et al. (2006), Mackenzie et al. (2005), Tiberi et al. (2005), and Tessema and Antoine (2004) (Table 1).

The cross-sectional model is taken directly from the gravity interpretation of Tessema and Antoine (2004). It consists of the sediments in the rift basins, the upper crust, the lower crust and the mantle lithosphere interspersed with the large and small magma bodies (Fig. 5A, B). Multiple model runs using the various possible magnitude extensional forces were conducted with the horizontal extensional forces applied to the edges of the models (Fig. 5A). Two series of models were tested; one with the magma bodies as "weak" or hot magmatic; one with the magma bodies modeled as "strong" or cooled.

The mapview model is based on Tessema and Antoine (2004) and a schematic interpretation of the consistent segment dimensions of $50 \mathrm{~km}$ (Ebinger and Casey, 2001; Wolfenden et al., 2004) (Fig. 5B). While some magma bodies may intrude the sedimentary /volcaniclastic basin fill, the main large igneous bodies are located in the continental crust. The models were constructed to better understand the distribution of stresses associated with changing strength in these large mafic bodies in the mid-crust at around 5-10 km and as such are mapview slices into the rift at that depth. The magma bodies are

Table 1

Physical properties of the elastic rift models. Colors correspond to Fig. 5.

\begin{tabular}{|l|c|c|c|}
\hline $\begin{array}{l}\text { Based on Tessema and Antoine (2004) } \\
\text { and basic rock mechanics }\end{array}$ & $\begin{array}{l}\text { Key to } \\
\text { cartoon } \\
\text { models }\end{array}$ & $\begin{array}{l}\text { Young's } \\
\text { modulos } \\
(\mathrm{Pa})\end{array}$ & $\begin{array}{l}\text { Density } \\
\left(\mathrm{kg} / \mathrm{m}^{3}\right)\end{array}$ \\
\hline Lower crust & & $5 \mathrm{e}+12$ & 2850 \\
\hline Upper crust & & $4 \mathrm{e}+12$ & 2590 \\
\hline Upper crust thinned & & $4 \mathrm{e}+12$ & 2590 \\
\hline Mantlelit hosphere & & $8 \mathrm{e}+12$ & 3200 \\
\hline Sediment & & $3.5 \mathrm{e}+12$ & 2560 \\
\hline Intrusion weak (Magma) & $1 \mathrm{e}+12$ & 3000 \\
\hline Intrusion strong (Cooled) & & $8 \mathrm{e}+12$ & 3000 \\
\hline Intrusion2 weak (Magma) & & $1 \mathrm{e}+12$ & 2800 \\
\hline Intrusion2 strong (Cooled) & $8 \mathrm{e}+12$ & 2800 \\
\hline
\end{tabular}




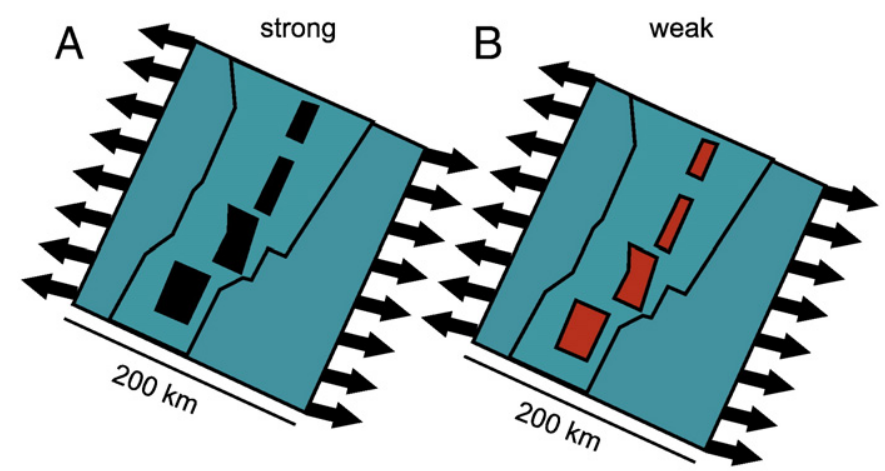

Fig. 5. Model schematics of elastic models. Cross-section cartoons of large-scale models, colors are as in Table 1 and reflect material properties of the models. A) Strong, cooled magmatic segments; B) weak magmatic segments. All models were tested using applied forces ranging from $1 \cdot 10^{12} \mathrm{~N} / \mathrm{m}$ to $1 \cdot 10^{16} \mathrm{~N} / \mathrm{m}$, force orientation is shown as vectors on the margins of the models. In the results no change in stress distribution or orientation was observed, only magnitude, so an applied stress of $1 \cdot 10^{14} \mathrm{~N} / \mathrm{m}$ was applied to all models as an approximation of the regional applied continental stresses.

modeled as "weak" or hot/magmatic and "strong" cooled/rock. The East African Rift along with the magma bodies are modeled as slightly thinner than the surrounding crust as indicated in the gravity profiles.

Increasing or decreasing the applied stress does not change the distribution of stress in either the mapview or cross-sectional model, and the stress in the crust is directly proportional to the amount of applied stress or force. The models therefore indicate which areas are likely to fail first when extensional stresses are applied and do not indicate how much stress is needed for failure. The greater the difference in strength between the magma bodies and the surrounding crust the greater the concentration or deflection of stress.

\subsubsection{Results}

Overall, the results indicate that when the magma bodies are hot and weak (i.e., shortly after intrusion) extensional stress is concentrated near segment tips while extensional deformation within the segments is accommodated by magmatic intrusions. Stresses do not build up as high within the magmatic segments for a certain amount of extension as they do when the magmatic bodies have cooled down. When the mafic intrusives are completely cooled and therefore stronger than the surrounding continental lithosphere the stress is distributed broadly within the thinned crust of Main Ethiopian Rift and concentrated within the cooled and strong magmatic segments, while the tips of the magmatic segments deflect stresses.

3.2.2.1. Mapview results (Fig. 6A, B). Two large-scale model results are presented here showing the effect of weak (magma injection stage) and strong (cooled) mafic segments in the Main Ethiopian Rift at a depth of $\sim 5-10 \mathrm{~km}$. Strong cooled mafic magma bodies concentrate stress within the broad Main Ethiopian Rift zone and in the segments, while magma injection phases concentrate stress in the strong continental crust between the segments. Extensional stress is also concentrated in the slightly thinner region of continental crust that comprises the center of the rift valley.

In Fig. 6A the strong magma bodies clearly concentrate the extensional stresses leaving areas of low extensional stress between the segments. This also results in some deflection of the stress between the magma bodies. Stress deflection appears greatest in the Boset Kone magmatic segment, which is located at the narrowing of the rift valley; the magmatic segment is also deviated in shape at this location. When the magmatic segments are modeled as being hot, weak intrusives, the extensional stress is concentrated in the continental crust surrounding them (Fig. 6B). The results indicate that the larger the segment, the greater the deflection and the greater the concentration of stress
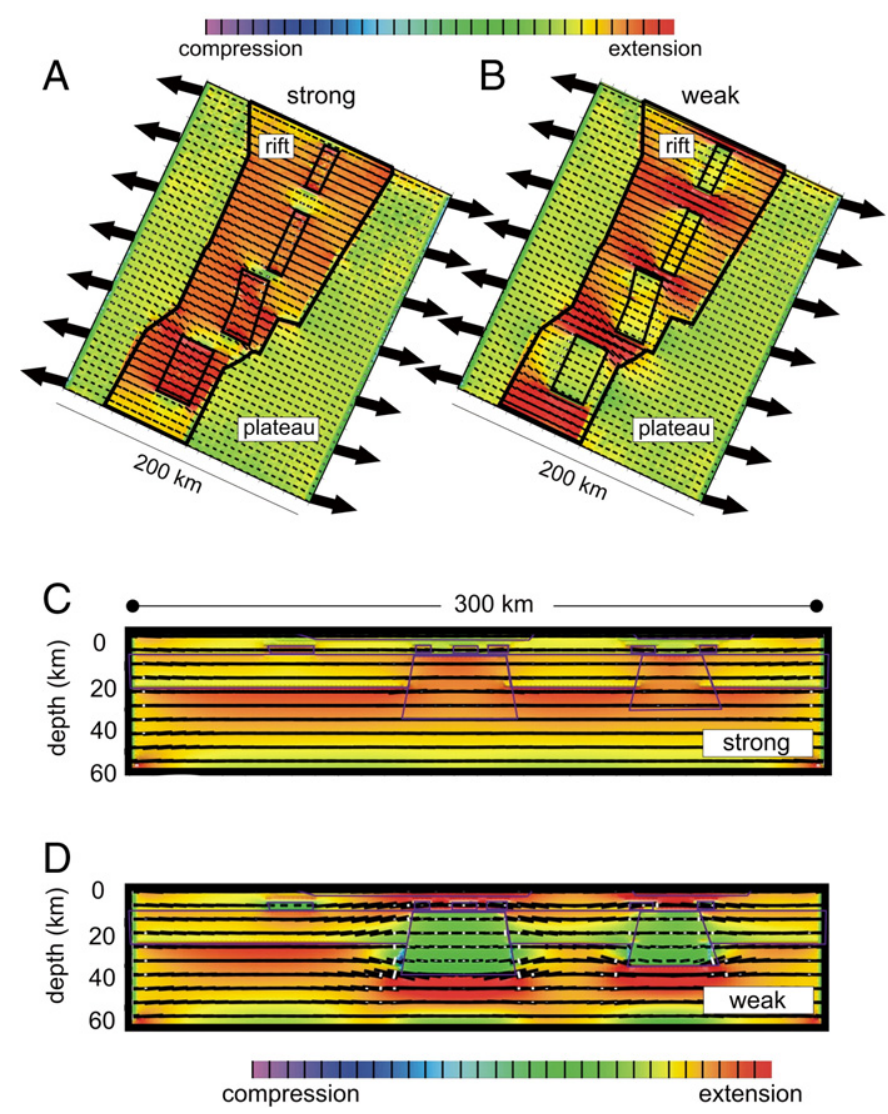

Fig. 6. A-B. Model results for strong and weak magmatic bodies are displayed in A and B. A) model results for strong magmatic bodies; B) results for weak magmatic bodies. Background colors indicate maximum stress magnitude and type (blue is compressional, red is extensional), small black and white bars indicate the maximum and minimum stress vectors (black is extensional, white is compressional). Black boxes outline material differences associated with the rift zone and the magmatic segments within it. Arrows on the edges of the results indicate the applied stress direction. C-D. Model results for cross-section of strong (C) and weak (D) magmatic segments in northern East African Rift. Background colors indicate maximum stress magnitude and type (blue is compressional, red is extensional), small black and white bars indicate the maximum and minimum stress vectors (black is extensional, white is compressional). Purple boxes outline material differences associated with the rift zone and the magmatic segments within it. Arrows on the edges of the results indicate the applied stress direction.

between the segments and in the segment ends. The models further predict that the stress field rotates in between the magmatic segments (Fig. 6A, B).

3.2.2.2. Cross-section results (Fig. 6C, D). Extensional stress applied to a cross-section model of thinned continental crust intruded by mafic magma bodies results in stress concentration within the continental crust and in the strong mantle lithosphere (Fig. 6C, D). Changing the strength of the intruded mafic bodies (ranging in size from a few kilometers to tens of kilometers) affects the distribution of stress in the lower crust, within, and above the mafic bodies, but it does not change the concentration of extensional stress in the mantle lithosphere. In all cross-section models it was also noted that boundaries between different strength and/or density layers resulted in a minor stress concentration.

In these large-scale cross-section models the mafic bodies were initially modeled as all either strong or weak (cooled or cooling) (Fig. 6A, B). When the mafic bodies are modeled as strong, they concentrate stress within the mafic bodies to a slightly lesser degree than the mantle lithosphere (Fig. 6A). However, because they are intruded into the weaker continental crust and sediments they act as stress 
concentrators at shallower depths. Thus, even though the actual stress magnitude is slightly less (order of 2-5) than the extensional stress in the mantle lithosphere, the stress differential between the mafic bodies and the continental crust is much higher (Fig. 6A). In the model with the weak mafic bodies (modeled as if the whole of the body had become magmatic and thereby hot and weak) extensional stress is concentrated around the bodies in the adjacent crust, as well as above and below the weak mafic body (Fig. 6B). The stress concentration above and below the weaker mafic bodies is up to an order of magnitude greater than the stress concentration in the mantle lithosphere or the surrounding continental crust.

\section{Discussion: Formation and stability of magmatic segments}

The models show that strain localization can be initiated by magma intrusions into continental crust within an extensional stress field. Magma intrusions localize fault formation that would border one or both sides of the magmatic segment. The strike and dip direction of the faults are controlled by the existing stress field, such that segments are formed that are oriented (sub-)orthogonal to the far-field stresses. Fig. 1 shows that the magmatic segments in the Ethiopian Rift and Afar regions are all bordered by normal faults. The re-distribution of strain within the MER and Afar regions that started at $3 \mathrm{Ma}$ and resulted in Quaternary magmatic segments, may have started with magma injections, which subsequently evolved into elongated narrow zones of deformation.

Once formed, both the cross-section and mapview elastic models show that strong, cooled mafic magmatic bodies act as stress focal points within the rift. Thus, once mafic magma has intruded and cooled, strain remains concentrated within the magmatic segments. Cracks, and probably dikes, would therefore be more likely to form in these areas. Thus, the models indicate that the observed magmatic segmentation of the MER may be self-induced such that once mafic bodies cooled within the continental crust, they acted as stress concentrators which in turn localized future magmatic activity around and in the pre-existing structures. The magmatic segments then act as focal points for renewed rising magma, which may account for the maintenance of magmatic segmentation through multiple rifting episodes prior to rupture and formation of oceanic lithosphere. During the time period of vertical accommodation, the flexural depression of the plate caused by the magmatic intrusive bodies may cause sills and basalt flows to dip toward the rift- or break-up axis in a geometry analogous to "seaward dipping reflectors".

The second model scenario, that of a weakened magmatic segment during a magma-injection phase, predicts that stress concentrates at the magmatic segment tips during periods of high magmatic activity. Segment propagation is both hampered and helped by the lack of preexisting strike-slip faults that allow for the opening of the segments. As shown in Beutel (2005) for mid-ocean ridge segments, the presence of a transform fault between weakened segments affects the concentration of stress at rift tips. When strike-slip faults begin to form between the segments we would expect the stress at the segment tips to be relieved during periods of high magmatic activity. It is when this happens that the segments will no longer be horizontally constrained and oceanic rift segments/ocean floor will begin to be created.

\subsection{Comparison with Ethiopian Rift deformation patterns}

The distribution of seismicity in the Ethiopian Rift supports a model of extensional stress focused by the intrusion of magma maintaining regular along-axis rift segmentation. South of the magmatic segments, earthquakes are distributed across a $50 \mathrm{~km}$-wide zone that includes the eastern rift flank border fault. This pattern of strain is consistent with the broad zone of collapse calderas and faults observed at the surface (e.g. Pizzi et al., 2006). Further north in the FentaleDofen magmatic segment, seismicity along the rift axis is predomi- nantly concentrated at 9-14 km depth within a narrower ( $30 \mathrm{~km}$ wide) axial graben that is coincident with a $20-30 \mathrm{~km}$-wide zone of mafic intrusions. Despite the Fentale-Dofen segment displaying elevated amount of seismicity during the year and a half of seismic recording, we see no evidence for intrusion of new dikes. Seismicity shows no clear spatial migration with time, and satellite radar data shows no measurable deformation expected from intrusion of a dike (e.g., Wright et al., 2006; Keir et al., 2009). Instead, the location, depth, and source mechanisms of seismicity are consistent with release of background extensional stress focused around a zone of cooled, mafic intrusions.

In the Boset magmatic segment, the amount of background seismicity is relatively low, and it occurs at shallower depth $(<10 \mathrm{~km})$ than adjacent segments. The presence of elevated amounts of partial melt in the upper crust within the Boset segment is supported by particularly high (5\%) crustal anisotropy (Keir et al., 2005), and low resistivity (1-3 $\Omega \mathrm{m}$ ) anomalies (Whaler and Hautot, 2006). SKS splitting delay times are also locally elevated by up to $1 \mathrm{~s}$ within the Boset segment compared to adjacent segments (Kendall et al., 2005) (Fig. 2). The $1 \mathrm{~s}$ magnitude of delay time increase suggests elevated concentration of partial melt is unlikely restricted to the upper crust, but rather extends through the lower crust and uppermost mantle. Locally elevated partial melt throughout the lithosphere, coupled with increased volumes of Quaternary/recent volcanic products at the Boset segment (Abebe et al., 2007), suggests the segment may be "weak" over relatively long time scales. Such observations suggest that the time-averaged along-axis segmentation of the rift that is observed in patterns of faults and aligned cones at the surface is also seen in the pattern of instantaneous along-axis variations in stress captured by seismicity. Thus, geophysical data show that these along-axis variations in stress are consistent with those predicted from variable crustal rheology. Existing paleomagnetic data show vertical axis rotations at the southern end of the Fentale-Dofan segment (Kidane et al., 2009), but are too sparse in the MER and southern Red Sea to test model predictions of vertical axis rotations (e.g., Kidane et al., 2006).

Insights to deformation and segment growth during transient phases of "weak" magmatic segments come from the rapidly deforming Dabbahu sector of the Red Sea Rift in the Afar depression (Fig. 1). During $\sim 2$ weeks in September 2005, a series of dike intrusions caused opening along a $60 \mathrm{~km}$-long rift segment previously mapped from field and satellite imagery (Hayward and Ebinger, 1996; Wright et al., 2006; Ayele et al., 2007; Rowland et al., 2007). As of August 2009, at least 12 additional dike intrusions have occurred, some of which extend beyond the originally mapped termination of the $60 \mathrm{~km}$-long Dabbahu segment (Keir et al., 2009; Hamling et al., 2009; Belachew et al., 2008). This centrally-fed, along-axis dike propagation matches patterns predicted in our models, as well as segment-long opening episodes predicted from earlier studies in the MER (Keir et al., 2006).

The models and geophysical data suggest that magmatic segmentation in the Main Ethiopian Rift results from magmatic intrusions that are localized in linear segments, oriented sub-orthogonal to the extension direction, similar to oblique slow-spreading ridge segmentation. Extensional stress is accommodated within the strong magmatic segments through the propagation of dikes. When magmatic activity ceases or during non-magmatic periods of extension, stresses may build up in the segments, and extensional deformation is accommodated by slip along faults within the segments, and to a lesser extent across the broad rift zone. The segments therefore remain the preferred location of magma injection during renewed rifting episodes, promoting the stability and longevity of the segments. It is only during periods when the entire magmatic segment becomes weak due to massive magmatic injections that extensional stress is concentrated at the segment tips. At this time the segments may lengthen or even trigger intrusion in adjoining segments, but the stability of the current segments and absence of transform faults suggests that stress distribution at the segment tips is not large enough at this time to propagate the segment as a whole. 


\section{Conclusions}

The Main Ethiopian Rift is in its final stages of continental rifting. Within the broad rift zone, extensional deformation has localized since $\sim 3 \mathrm{Ma}$ in narrow magmatic segments, that are oriented oblique to the orientation of the Miocene border faults, but (sub-) orthogonal to the extension direction. This structure resembles oblique slowspreading mid-ocean ridges such as the Mohns Ridge and Reykjanes Ridge, where magmatic segments are stable, long-lived features of the plate boundary facilitated by frequent magma intrusions. We studied the formation and stability of the magmatic segments and the role of magma intrusions in the Main Ethiopian Rift by modeling the lithospheric stress field during several phases of magma body emplacement and cooling. Initiation of the magmatic segments is shown to result from magma injections, which focus strain in elongated zones. During magmatic phases of segment evolution the segments are weak, and extensional stresses localize at the rift tips, which may eventually result in lengthening of a segment. During amagmatic phases of extension, the numerical models predict strain localization within the magmatic segments and, to a lesser extent, broadly distributed extension within the rift zone. This promotes segment stability; the segments remain the preferred location for magma intrusion during new magmatic phases. The models further predict rotation of stresses in the accommodation zones between the en echelon segments. Flexure of the lithospheric plate expected to result from cooled magma bodies is too small to be detected in existing data, but it may cause basalt flows to dip toward the segment axis.

We applied these results to the formation and maintenance of MER segmentation. The several phases of magmatic and non-magmatic extension and the model predicted related stress patterns are recognized in several magmatic MER segments. Geophysical data are consistent with the presence of partial melt in the crust beneath the Boset segment. Shallower-depth of seismicity and predominance of sub-horizontal, rift parallel focal mechanism $P$ axes are consistent with that predicted for rheologically "weak" segment in a magmatic phase. The Fentale-Dofen segment is currently in a non-magmatic phase of extension, while south of the magmatic segments, earthquakes are distributed across a $50 \mathrm{~km}-$ wide rift zone. In contrast, the Dabbahu segment in the Red Sea Rift is currently experiencing a rifting episode and therefore in a transient magmatic cycle. The pattern of instantaneous localized deformation, seismicity, and dike intrusions propagating beyond the tip of the magma segments occurs as predicted by the models.

These results suggest that magma intrusions are responsible for the formation and stability of the segmentation within the northern MER and the Afar rift. Thus, these late-stage continental rift segments are similar to the structures and processes found on slowly spreading oblique mid-ocean ridges, indicating that mid-ocean ridge segmentation initiates prior to continental break-up, and prior to the formation of transform faults.

\section{Acknowledgments}

We like to thank Giacomo Corti, Manahloh Belachew, and Ian Bastow for discussions, two anonymous reviewers for very helpful and constructive comments, and Julie Rowland for her review. Funding for this study comes from NSF grant EAR 0635789. DBK and CJE acknowledge NERC grant NER/A/S/2000/01004, studentship NER/A/ S/2000/01004d, ERC fellowship to DK NE/E013945/1, and fellowship NERC Urgency NE/D008611/1.

\section{References}

Abebe, B., Acocella, V., Korme, T., Ayalew, D., 2007. Quaternary faulting and volcanism in the Main Ethiopian Rift. J. Afr. Earth Sci. 48, 115-124. doi:10.1016/j.jafrearsci.2006.10.005. Acocella, V., Korme, T., 2002. Holocene extension direction along the Main Ethiopian Rift, East Africa. Terra Nova 14, 191-197.
Asfaw, L.M., 1992. Seismic risk at a site in the East-African rift system. Tectonophysics 209, 301-309.

Audin, L., Quidelleur, X., Coulié, E., Courtillot, V., Gilder, S., Manighetti, I., Gillot, P., Tapponnier, P., Kidane, T., 2004. Palaeomagnetism and $\mathrm{K}-\mathrm{Ar}$ and ${ }^{40} \mathrm{Ar} /{ }^{39} \mathrm{Ar}$ ages in the Ali Sabieh area (Republic of Djibouti and Ethiopia): constraints on the mechanism of Aden ridge propagation into southeastern Afar during the last $10 \mathrm{Myr}$. Geophys. J. Int 158, 327-345.

Ayalew, D., Ebinger, C., Bourdon, E., Wolfenden, E., Yirgu, G., Grassineau, N., 2006. Temporal compositional variation of syn-rift rhyolites along the western margin of the southern Red Sea and northern Main Ethiopian Rift: Geol. Soc. London Spec. Publ., vol. 259, pp. 121-130. doi:10.1144/GSL.SP.2006.259.01.10.

Ayele, A., Kulhánek, O., 2000. Reassessment of source parameters for three major earthquakes in the East African rift system from historical seismograms and bulletins. Annali di Geofisica 43, 81-94.

Ayele, A., Jacques, E., Kassim, M., Kidane, T., Omar, A., Tait, S., Nercessian, A., de Chabalier, J.B., King, G., 2007. The volcano-seismic crisis in Afar, Ethiopia, starting September 2005. Earth Planet. Sci. Lett. 48, 70-79.

Bastow, I.D., Stuart, G.W., Kendall, J.-M., Ebinger, C.J., 2005. Upper mantle seismic structure in a region of incipient continental break-up: northern Main Ethiopian rift. Geophys. J. Int. 162, 479-493. doi:10.1111/j.1365-246X.2005.02666.x.

Bastow, I.D., Nyblade, A.A., Stuart, G.W., Rooney, T.O., Benoit, M.H., 2008. Upper mantle seismic structure beneath the Ethiopian hotspot: rifting at the edge of the African low velocity anomaly. Geochem. Geophys. Geosyst. doi:10.1029/2008GC002107.

Belachew, M., Ebinger, C., Campbell, E., Keir, D., Hammond, J., Hamling, I., Baker, L., and Ayele, A., 2008. Time and length scales of dike intrusions and associated faulting in the ongoing Afar rifting episode. Eos Trans. AGU, 89(53), Fall Meet. Suppl., Abstract T43A-1985.

Bendick, R., McClusky, S., Bilham, R., Asfaw, L., Klemperer, S., 2006. Distributed NubiaSomalia relative motion and dike intrusion in the Main Ethiopian rift. Geophys. J Int. 165, 303-310.

Benoit, M.H., Nyblade, A.A., VanDecar, J.C., 2006. Upper mantle P-wave speed variations beneath Ethiopia and the origin of the Afar hotspot. Geology 34, 329-332,.

Beutel, E.K., 2005. Stress-induced seamount formation at ridge-transform intersections. Geol. Soc. Am. Spec. Paper 338, 581-593.

Bilham, R., Bendick, R., Larson, K., Braun, J., Tesfaye, S., Mohr, P., Asfaw, L., 1999. Secular and tidal strain across the Ethiopian rift. Geophys. Res. Lett. 27, 2789-2984.

Boccaletti, M., Bonini, M., Mazzuoli, R., Abebe, B., Piccardi, L., Tortorici, L., 1998 Quaternary oblique extensional tectonics in the Ethiopian Rift (Horn of Africa). Tectonophysics $287,97-116$

Bonini, M., Souriot, T., Boccaletti, M., Brun, J.P., 1997. Successive orthogonal and oblique extension episodes in a rift zone: laboratory experiments with application to the Ethiopian rift. Tectonics 16, 347-362.

Bosworth, W., 1987. Off-axis volcanism in the Gregory rift, east Africa: implications for models of continental rifting. Geology 15, 397-400.

Casey, M., Ebinger, C., Keir, D., Gloaguen, R., Mohammed, F., 2006. Strain accommodation in transitional rifts: extension by magma intrusion and faulting. Geol. Soc London Spec. Pub 259, 143-164.

Chapin, C.E., Cather, S.M., 1994. Tectonic setting of the axial basins of the northern and central Rio Grande rift. Geol. Soc. Am. Spec. Paper 291, 5-25.

Chu, D.H., Gordon, R.G., 1999. Evidence for motion between Nubia and Somalia along the Southwest Indian Ridge. Nature 398, 64-67.

Cornwell, D.G., Mackenzie, G.D., Maguire, P.K.H., England, R.W., Asfaw, L.M., Oluma, B., 2006. Northern Main Ethiopian Rift crustal structure from new high-precision gravity data. Geol. Soc. London Spec. Publ 259, 309-323.

Corti, G., 2008. Control of rift obliquity on the evolution and segmentation of the main Ethiopian rift. Nature Geosci. 1, 258-262.

Corti, G., van Wijk, J., Cloetingh, S., Morley, C.K., 2007. Tectonic inheritance and continental rift architecture: numerical and analogue models of the East African Rift system. Tectonics 26. doi:10.1029/2006TC002086.

Daly, E., Keir, D., Ebinger, C.J., Stuart, G.W., Bastow, I.D., Ayele, A., 2008. Crustal tomographic imaging of a transitional continental rift: the Ethiopian rift. Geophys. J. Int. 172, 1033-1048. doi:10.1111/j.1365-246X.2007.03682.x.

Dauteuil, O., Brun, J.-P., 1996. Deformation partitioning in a slow spreading ridge undergoing oblique extension: Mohns Ridge: Norwegian Sea. Tectonics 15, 870-884 doi:10.1029/95TC03682.

Dugda, M.T., Nyblade, A.A., Julià, J., Langston, C.A., Ammon, C.A., Simiyu, S., 2005. Crustal structure in Ethiopia and Kenya from receiver function analysis. J. Geophys. Res. 110 doi:10.1029/2004JB003065.

Ebinger, C.J., 1989. Geometric and kinematic development of border faults and accommodation zones, Kivu-Rusizi rift, Africa. Tectonics 8, 117-133.

Ebinger, C.J., Casey, M., 2001. Continental break-up in magmatic provinces: an Ethiopian example. Geology 29, 527-530.

Ebinger, C.J., Rosendahl, B.R., Reynolds, D.J., 1987. Tectonic model of the Malawi rift, Africa. Tectonophysics 141, 215-235.

Ebinger, C.J., Jackson, J.A., Foster, A.N., Hayward, N.J., 1999. Extensional basin geometry and the elastic lithosphere. Phil. Trans. Math. Phys. Engin. Sci. 357, 741-765.

Ebinger, C.J., Yemane, T., Harding, D., Tesfaye, S., Kelley, S., Rex, D.C., 2000. Rift deflection, migration, and propagation: linkage of the Ethiopian and Eastern rifts, Africa Geol. Soc. Am. Bull. 112, 163-176.

Fernandes, R.M.S., Ambrosius, B.A.C., Noomen, R., Bastus, L., Combrinck, L., Miranda, J.M., Spakman, W., 2004. Angular velocity of Nubia and Somalia from continuous GPS data: implications on present-day relative kinematics. Earth Planet. Sci. Lett. 222, 197-208,

Furman, T., Bryce, J., Rooney, T., Hanan, B., Yirgu, G., Ayalew, D., 2006. Heads and tails: 30 million years of the Afar plume. Geol. Soc. London Spec. Publ. 259, 97-121.

Géli, L., Renard, V., Rommevaux, C., 1994. Ocean crust formation processes at very slow spreading centers; a model for the Mohns Ridge, near $72^{\circ} \mathrm{N}$, based on magnetic gravity and seismic data. J. Geophys. Res. 99, 2995-3013. doi:10.1029/93JB02966. 
Gobat, J.I., Atkinson, D.C., 1999. The FElt system: User's guide and reference manual. Computer Science Technical Report CS94- 376, Department of Computer Science and Engineering, University of California, San Diego, CA.

Hamling, I.J., Ayele, A., Bennati, L., Calais, E., Ebinger, C.J., Keir, D., Lewi, E., Wright, T.J. Yirgu, G., 2009. Geodetic observations of the ongoing Dabbahu rifting episode: new dyke intrusions in 2006 and 2007. Geophys. J. Int. 178, 989-1003. doi:10.1111/j. 1365-246X.2009.04163.x.

Hayward, N., Ebinger, C., 1996. Variations in along-axis segmentation of the Afar rift system. Tectonics $15,244-257$.

Hofmann, C., Courtillot, V., Feraud, G., Rochette, P., Yirgu, G., Ketefo, E., Pik, R., 1997. Timing of the Ethiopian flood basalt event: implications for plume birth and global change. Nature 389, 838-841.

Hofstetter, R., Beyth, M., 2003. The Afar Depression: interpretation of the 1960-2000 earthquakes. Geophys. J. Int 155, 715-732.

Jackson, J., Blenkinsop, T., 1997. The Bilila-Mtakataka fault in Malawi: an active, 100-km long, normal fault segment in thick seismogenic crust. Tectonics 16, 137-150.

Keir, D., Kendall, J.-M., Ebinger, C.J., Stuart, G.W., 2005. Variations in late syn-rift melt alignment inferred from shear-wave splitting in crustal earthquakes beneath the Ethiopian rift. Geophys. Res. Lett. 32, L23308. doi:10.1029/2005GL024150.

Keir, D., Ebinger, C.J., Stuart, G.W., Daly, E., Ayele, A., 2006. Strain accommodation by magmatism and faulting as rifting proceeds to break-up: seismicity of the northern Ethiopian rift. J. Geophys. Res 111, B05314. doi:10.1029/2005JB 003748.

Keir, D., Hamling, I.J., Ayele, A., Calais, E., Ebinger, C., Wright, T.J., Jacques, E., Mohamed, K., Hammond, J.O.S., Belachew, M., Baker, E., Rowland, J.V., Lewi, E., Bennati, L., 2009. Evidence for focused magmatic accretion at segment centers from lateral dike injections captured beneath the Red Sea rift in Afar. Geology 37, 59-62.

Kendall, J.-M., Stuart, G., Ebinger, C., Bastow, I., Keir, D., 2005. Magma-assisted rifting in Ethiopia. Nature 433, 146-148.

Kendall, J.-M., Pilidou, S., Keir, D., Bastow, I.D., Stuart, G.W., Ayele, A., 2006. Mantle upwellings, melt migration and the rifting of Africa: insights from seismic anisotropy. Geol. Soc. London Spec. Publ 259, 271-293.

Keranen, K., Klemperer, S., 2008. Discontinuous and diachronous evolution of the Main Ethiopian Rift: implications for development of continental rifts. Earth Planet. Sci. Lett. 265, 96-111.

Keranen, K., Klemperer, S., Gloaguen, R., EAGLE Working Group, 2004. Imaging a protoridge axis in the Main Ethiopian rift. Geology 39, 949-952.

Kidane, T., Platzman, E., Ebinger, C., Abebe, B., Rochette, P., 2006. Palaeomagnetic constraints on continental break-up processes: observations from the Main Ethiopian Rift. Geol. Soc. London Spec. Publ. 259, 165-183.

Kidane, T., Otofuji, Y.I., Komatsu, Y., Shibasaki, H., Rowland, J., 2009. Paleomagnetism of the Fentale-magmatic segment, main Ethiopian Rift: new evidence for counterclockwise block rotation linked to transtensional deformation. Phys. Earth Planet. Int 176, 109-123.

Kieffer, B., Arndt, N., Lapierre, H., Bastien, F., Bosch, D., Pecher, A., Yirgu, G., Ayalew, D. Weis, D., Jerram, D.A., Keller, F., Meugniot, C., 2004. Flood and shield basalts from Ethiopia: magmas from the African superswell. J. Petrol. 45, 793-834.

Li, F., Dyt, C., Griffiths, C., 2004. 3D modeling of flexural isostatic deformation. Comput Geosci. 30, 1105-1115.

Mackenzie, G.D., Thybo, H., Maguire, P.K.H., 2005. Crustal velocity structure across the Main Ethiopian Rift: results from 2-dimensional wide-angle seismic modeling. Geophys. J. Int. 162, 994-1006. doi:10.1111/j.1365-246X.2005.02710.x.

Maguire, P.K.H., Keller, G.R., Klemperer, S.L., Mackenzie, G.D., Harder, S., O'Reilly, B. Thybo, H., Asfaw, L., Khan, M.A., Amha, M., 2006. Crustal structure of the northern Main Ethiopian Rift from the EAGLE controlled-source survey; a snapshot of incipient lithospheric break-up. Geol. Soc. London Spec. Publ. 259, 271-293.

Meyer, W., Pilger, A., Rosler, A., and Stets, J., 1975. Tectonic evolution of the northern part of the Main Ethiopian rift in southern Ethiopia. Pilger, A. and Rösler, A. (eds) Afar Depression of Ethiopia, E. Schweizer. Verlagsbuchhandl. (Naegele u. Obermiller) Stuttgart, Federal Republic of Germany, 352-362.
Mohr, P.A., 1968. Transcurrent faulting in the Ethiopian Rift system. Nature 218, 938-941.

Montelli, R., Nolet, G., Dahlen, F.A., Engdahl, E.R., Hung, S.H., 2004. Finite. frequency tomography reveals a variety of plumes in the mantle. Science 303, 338-343.

Moresi, L.N., Dufour, F., Mühlhaus, H.B., 2003. A Lagrangian integration point finite element method for large deformation modeling of viscoelastic geomaterials. J. Comput. Phys. 184, 476-497.

Moresi, L.N., Mühlhaus, H.B., Lemiale, V., May, D., 2007. Incompressible viscous formulations for deformation and yielding of the lithosphere. Geol. Soc. London Spec. Publ. 282, 457-472.

Morley, C.K., Nelson, R.A., Patton, T.L., Munn, S.G., 1990. Transfer zones in the East African Rift system and their relevance to hydrocarbon exploration in rifts. AAPG Bulletin 74, 1234-1253.

Pik, R., 2003. Stability of the upper Nile drainage network (Ethiopia) deduced from (U- Th)/ He thermochronometry; implications for uplift and erosion of the Afar Plume. Earth Planet. Sci. Lett. 215, 73-88.

Pizzi, A., Coltorti, M., Abebe, B., Disperati, L., Sacchi, G., Salvini, R., 2006. The Wonji fault belt (Main Ethiopian rift): structural and geomorphological constraints and GPS monitoring. Geol. Soc. London Spec. Publ. 259, 191-207.

Ranalli, G., 1995. Rheology of the Earth2nd edition. Chapman \& Hall. 413 pp.

Rooney, T.O., Furman, T., Yirgu, G., Ayalew, D., 2005. Structure of the Ethiopian lithosphere: xenolith evidence in the Main Ethiopian Rift. Geochemica et Cosmochimica Acta 69, 3889-3910. doi:10.1016/j.gca.2005.03.043.

Rooney, T., Furman, T., Bastow, I., Ayalew, D., Yirgu, G., 2007. Lithospheric modification during crustal extension in the Main Ethiopian Rift. J. Geophys. Res. 112, B10201.

Rowland, J.V., Baker, E., Ebinger, C.J., Keir, D., Kidane, T., Biggs, J., Hayward, N., Wright, T.J., 2007. Fault growth at a nascent slow-spreading ridge: 2005 Dabbahu rifting episode, Afar. Geophys. J. Int 171, 1226-1246.

Tessema, A., Antoine, L.A.G., 2004. Processing and interpretation of the gravity field of the East African rift: implication for crustal extension. Tectonophysics 394, 87-110. doi: $10.1016 / j$.tecto.2004.07.057.

Tiberi, C., Ebinger, C., Ballu, V., Stuart, G., Oluma, B., 2005. Inverse models of gravity data from the Red Sea-Aden-East African rifts triple junction zone. Geophys. J. Int 163, 775-787.

Upcott, N.M., Mukasa, R.K., Ebinger, C.J., 1996. Along-axis segmentation and isostasy in the Western rift, East Africa. J. Geophys. Res. 101, 3247-3268.

van Wijk, J.W., 2005. Role of weak zone orientation in continental lithosphere extension. Geophys. Res. Lett. 32, L02303. doi:10.1029/2004GL022192.

van Wijk, J.W., Blackman, D.K., 2007. Development of en echelon magmatic segments along oblique spreading ridges. Geology 35, 599-602. doi:10.1130/G23294A.1.

Vigny, C., Huchon, P., Ruegg, J., Khanbari, K., Asfaw, L.M., 2006. Confirmation of Arabia plate slow motion by new GPS data in Yemen. J. Geophys. Res. 111, B02402. doi:10.1029/ 2004JB003229.

Whaler, K.A., Hautot, S., 2006. The electrical resistivity structure of the crust Beneath the northern Main Ethiopian Rift. Geol. Soc. London Spec. Publ. 259, 293-305.

WoldeGabriel, G., Aronson, J., Walter, R., 1990. Geology, geochronology, and rift basin development in the central sector of the Main Ethiopian rift. Geol. Soc. Am. Bull. 102, 439-458.

Wolfenden, E., Ebinger, C., Yirgu, G., Deino, A., Ayalew, D., 2004. Evolution of the northern Main Ethiopian rift: birth of a triple junction. Earth Planet. Sci. Lett. 224, 213-228.

Wolfenden, E., Ebinger, C., Yirgu, G., Renne, P., Kelley, S.P., 2005. Evolution of the southern Red Sea rift: birth of a magmatic margin. Bull. Geol. Soc. Am. 117, 846-864.

Wright, T.J., Ebinger, C., Biggs, J., Ayele, A., Yirgu, G., Keir, D., Stork, A., 2006. Magmamaintained rift segmentation at continental rupture in the 2005 Afar dyking episode. Nature 442, 291-294. 